\title{
ANTIVIRAL COMBINATION APPROACH AS A PERSPECTIVE TO COMBAT ENTEROVIRUS INFECTIONS
}

\author{
Angel S. Galabov, Ivanka Nikolova, Ralitsa Vassileva-Pencheva and Adelina Stoyanova
}

The Stephan Angeloff Institute of Microbiology, Bulgarian Academy of Sciences, Sofia, Bulgaria

Corresponding Author: Angel S. Galabov, Stephan Angeloff Institute of Microbiology, Bulgarian Academy of Sciences, Sofia, Bulgaria, 26 Georgi Bonchev str., Sofia 1113, Bulgaria, Tel. +359 2979 31 57; Fax: +359 28700109 , E-mail: micb@microbio.bas.bg



\begin{abstract}
Human enteroviruses distributed worldwide are causative agents of a broad spectrum of diseases with extremely high morbidity, including a series of severe illnesses of the central nervous system, heart, endocrine pancreas, skeleton muscles, etc., as well as the common cold contributing to the development of chronic respiratory diseases, including the chronic obstructive pulmonary disease. The above mentioned diseases along with the significantly high morbidity and mortality in children, as well as in the high-risk populations (immunodeficiencies, neonates) definitely formulate the chemotherapy as the main tool for the control of enterovirus infections. At present, clinically effective antivirals for use in the treatment of enteroviral infection do not exist, in spite of the large amount of work carried out in this field. The main reason for this is the development of drug resistance. We studied the process of development of resistance to the strongest inhibitors of enteroviruses, WIN compounds (VP1 protein hydrophobic pocket blockers), especially in the models in vivo, Coxsackievirus B (CV-B) infections in mice. We introduced the tracing of a panel of phenotypic markers $\left(\mathrm{MIC}_{50}\right.$ value, plaque shape and size, stability at $50^{\circ} \mathrm{C}$, pathogenicity in mice) for characterization of the drug-mutants (resistant and dependent) as a very important stage in the study of enterovirus inhibitors. Moreover, as a result of VP1 RNA sequence analysis performed on the model of disoxaril mutants of CVB1, we determined the molecular basis of the drug-resistance.

The monotherapy courses were the only approach used till now. For the first time in the research for anti-enterovirus antivirals our team introduced the testing of combination effect of the selective inhibitors of enterovirus replication with different mode of action. This study resulted in the selection of a number of very effective in vitro double combinations with synergistic effect and a broad spectrum of sensitive enteroviruses. The most prospective attainment in our examinations in this field was the development of a novel scheme for the combined application of anti-enteroviral substances in coxsackievirus B1 neuroinfection in newborn mice. It consisted of a consecutive, alternating and non-
\end{abstract}


simultaneous administration of the substances in the combination. The triple combination - disoxaril-guanidine. HCl-oxoglaucine (DGO) showed a high effectiveness expressed in the marked reduction of the mortality rate in infected mice as compared both to the placebo group, and to the partner compounds used alone every day, and to the same combination applied simultaneously every day. The studies of the drug sensitivity of viral brain isolates from mice treated with DGO combination showed not only preserved, but even increased sensitivity to the drugs included in the combination. Obviously, the consecutive alternating administration of anti-enteroviral substances hinders the occurrence of drug-resistance in the course of the experimental enteroviral infections in mice.

Key words: enteroviruses, antivirals, drug-resistance, combination effects.

\section{Enteroviruses in human pathology}

Human enteroviruses, members of a large genus in the Picornaviridae family, are distributed worldwide and represent the most common of human viruses, possibly infecting a billion or more individuals annually and resulting in hundreds of thousands of hospitalizations per year in the developed world only (Pallansch, 2011). Enteroviruses are very efficient infective agents although the majority of infections are asymptomatic or mild in their clinical course (Morens, 1995; Pallansch, 2006; Strauss, 2008). The contagiousness is such that actually, if an individual in a given group developed the symptoms of an enteroviral infection, it would be certain that all members of the group were infected (Pallansch, 2011). Alongside the asymptomatic or mild clinical course of the majority of infections, a wide variety of diverse syndromes and diseases are associated with non-polio enterovirus infections. The most common clinical manifestation is the upper respiratory tract discomfort (Chuang, 2010), fever, and, occasionally, mild gastrointestinal symptoms (Morens, 1995). But non-polio enteroviruses may cause a broad spectrum of diseases due to their ability to affect various organs and systems including the central nervous system, the respiratory system, the skin, the heart, the pancreas, the eyes. The most common tissue specific localization of the enteroviral infection is the central nervous system, resulting in aseptic meningitis, or much more rarely, in encephalitis. Some enteroviruses may manifest tropism to other definite tissues like the cardiotropic coxsackieviruses or those viruses affecting the pancreatic beta cells, but the tropism is neither unique, nor specific (Archard, 1987; Tauriainen, 2011). Disseminated infection can lead to exanthema, non-specific myalgias or se- vere multiorgan disease in neonates (Morens, 1995). Individual serotypes can be associated with different clinical manifestations and vice versa, a particular clinical manifestation can be caused by several different serotypes (Strauss, 2008). Severe and life-threatening conditions, such as meningitis, encephalitis, neonatal sepsis, myocarditis, pancreatitis, as well as further complications and some chronic diseases later in life, i.g. insulin dependent type 1 diabetes mellitus (Hyoty, 2002; Galabov and Angelova, 2006) and dilated cardiomyopathy (Schultheiss, 2006) can be attributed to an enterovirus infection, especially early in life. Symptomatic infections include also the summer cold, herpangina, hand-foot-and-mouth disease, pleurodynia (Bornholm disease), rashes, hemorrhagic conjunctivitis, uveitis, chronic fatigue syndrome. Human rhino viruses, which comprise another numerous group within the enterovirus genus, cause the common cold in individuals of all ages contributing to the possible development or exacerbation of chronic respiratory diseases later in life (Tan, 2005; Mallia, 2007). All enteroviruses due to their high stability in the environment can also be the causative agents of nosocomial outbreaks, particularly severe in neonatal units and nurseries (Aitken, 2001).

\section{Chemotherapy in the control of enterovirus infections}

As the number of human enteroviruses is quite big and their mutation rate is rather high, it is considered that efforts for the development of a successful vaccine would not lead to an efficient control. This definitely formulates chemotherapy as the main tool to overcome the infection. What is more, the new strategy for poliomyelitis eradication claims for the development of safe and efficient anti-polio drugs. 
More than a thousand substances have been screened and characterized as selective inhibitors of enterovirus replication after testing in cell culture experiments (Table 1). But a sharp discrepancy exists between the antiviral activity established in cell culture in vitro and testing in laboratory animals in vivo. Less than 20 out of hundreds inhibitors manifested some in vivo activity. The next table (Table 2) presents the results from the clinical trials for antienteroviral chemo-therapeutics carried out following the double-blind placebo-controlled schedule in which there were involved compounds inhibiting enterovirus replication.

Evidently, the anti-enteroviral chemotherapy is still a problem open for the future.

Table 1

Antivirals active vs. enteroviruses in vitro

A. Inhibitors of early replication stages (mainly capsid binding compounds)

- WIN compounds (Sterling-Winthrop):_arildone [4-[6-(2-chloro-4-methoxyphenoxy) hexyl] 3,5-heptadion] (WIN38020); disoxaril [5-[7-[4(4,5-dihydro-2-oxazolyl)phenoxy] heptyl]-3-methyl-izoxazole] (WIN51711); WIN54954; pleconaril [3-3,5-dimethyl-4-[(3-methyl- 5-isoxazolyl)propyl]-5- (trifluoromethyl)-2,4-oxadiazole] (WIN61893).

- Pyridazinamine analogues (R compounds) (Janssen Research Foundation): R 77975 (Pirodavir) [ethyl p-(2(1-(6-methyl-3-pyridazinyl)-4-piperidyl)ethoxy) benzoate]; R 61837;

R 78206; BTA-39; BTA-188; BTA-798 (Biota).

- Imidazole derivatives (Schering-Plough): SCH 38057 [1-[6-(2-chloro-4-methoxy)-hexyl]imidazol hydrochloride]; SCH 47802; SCH 48973.

- Isoxazole derivatives: compounds VIa,19, 20, 21.

- Pyridil imidazolidinones: BPROZ-194 [1-[5-(4-bromophenoxy)pentyl]-3-(4-pyridyl)-2-imidazolidinone]; DBPR 103; compounds 8b,14a, 28b.

- Phenoxybenzenes, phenoxypyridines and related analogues (Merrell Dow): MDL-860 [2-(3,4-dichlorophenoxy)-5-nitrobenzonitrile] (DNB) ${ }^{*}$; compounds 71, 13, 21; DEPC [6-(3,4-dichlorophenoxy)-3-(ethylthio)-2-pyridine carbonitrile].

- Pyranopyridines (Merrell Dow):_MDL 20,610 [6-substituted 2-(3,'4'dichlorophenoxy) -2H-pyrano[2,3b]pyridines]; MDL 20,646; MDL 20,957.

- Flavine derivatives:_BW 683C (4,6-dichloroflavane); BW 4294 (1-anilino-9-benzyl-2-chloropurine); 4',6dicyanoflavan; $3(2 \mathrm{H})$-isoflavene.

- Chalcones (Ro compounds) (Roche): Ro 09-0410 [4'-ethoxy-2'-hydroxy-4,6'dimeth-oxychalcone]; Ro 090696; Ro 09-0881.

- Methylthiopyrimidines: S-7: Ethyl-2-methylthio-4-methyl-5-pyrimidine carboxylate

- Rhodanine [2-thio-4-oxothiazolidine; ethylene thiourea]

- 44081 [2-[(1,5,10,10a-tetrahydro-3H-thiazolo[3,4b]isoquinolin-3-ylidene)amino]-4-thiazoleacetic acid]

- Dibenzofuran and related compounds

B. Inhibitors of virus-specific RNA synthesis

- Guanidine hydrochloride.

- N,N'-Diphenylthioureas: PTU-23 [N-phenyl-N'-2-hydroxyphenylthiourea]; PTU-20; PTU-24.

- Benzimidazoles: HBB [2- $\alpha$-hydroxybenzyl-benzimidazole]; enviroxime [2-amino-1-(isopropylsulfonyl)-6benzimidazole phenyl ketonoxim (LY 122771-72); enviroxime-related derivatives (vinylacetylene benzimidazoles); enviradene: (E)-1-[(1-methyletyl)sulfonyl]-6-(1-phenyl-1-propenyl)-1H-benzimidazole-2-amine; compound 12; C2analogue with 2-amino substitution; imidazo[1,2-b]pyridazine analogues; imidazo[1,2-a]pyridines; MRL-1237 [1-(4fluorophenyl)-2-(4-imino-1,4-dihydropyridin-1-yl)methylbenimidazole hydrochloride]; TBZE-029 [1-(2,6-diflurophenyl)-6-trifluoromethyl-1H,3H-thiazolo[3,4-a]benimidazole].

- Gliotoxin: Inhibitor of an early event in the virus replication after initial uncoating

- Isothiazole derivatives: DID [5,5'-diphenyl-3,3'-diisothiazole disulfide].

- Flavones: 3-methylquercetin (3-MQ); Ro 09-0179 [4',5'-dihydroxy-3,3',7-trimeth-oxyflavone]; 3-methylkaempferol; 3,4'-dimethylkaempferol; 2-styrylchromones vinylogues flavones.

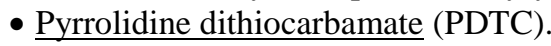

C. Virus-specific protease inhibitors (attacking virus specific proteases $2 \mathrm{~A}$ and $3 \mathrm{C}$ ):

- Peptidic inhibitors: Peptide aldehydes: tripeptyde aldehyde; rupintrivir (AG7088): ethyl(2E,4S)-4-((2R,5S)2-(4-fluorobenzyl)-6-methyl-5-(((5-methylisoxazol-3-yl) carbonyl) amino)-4-oxoheptanoyl)amino)-5-((3S)-2-oxopyrrolidin-3-yl)pent-2-enoate (Pfizer);diazo- methyl ketones (DMK): tripeptidyl-DMK; peptidyl monofluoromethyl ketones; peptidyl $\mathrm{N}$-iodoacetamides. 
- Non-peptidic inhibitors: 2-pyridone-containing peptidomimetics (compounds XIX, XX, XXI); substituted benzmides (compound XXIII); homophthalamides (compound XXVI).

- Elastase-specific inhibitors : methoxysuccinyl-Ala-Ala-Pro-Val-chloromethylketone (MCPK); elastinal.

- Homophthalamides: compound XV.

\section{Antivirals with other mechanism of action}

- Ribavirin: 1- $\beta$-D-ribofuranozyl-1,2,4-triazole-3-carboxamide.

- Hydantoin [5-(3,4-dichlorophemyl)methylhydantoin.

- Hydrophyllic compounds: hygromycin B.

- Aziridine and N-dansylaziridine.

Table 2

Inhibitors of Enterovirus Replication in Clinical Trials

- Disoxaril (WIN51711) - poor bio-availability; crystalluria in healthy volunteers (Phase I) stopped further clinical development.

- WIN 54954 - well tolerated in Phase I; applied orally it effectively reduced the severity of coxsackievirus A21-induced natural mild respiratory infections; lack of effect against experimentally induced infections caused by rhinovirus 23 and 29 (Tutner et al., 1993); rapidly metabolized; induced reversible hepatitis (Diana et al., 1995); adverse effects (flushing, rush) precluded further development.

- Pleconaril (WIN63843) - rate of metabolism strongly reduced (Diana et al., 1995); displayed some efficacy in 2 of 3 neonates with enteroviral hepatitis (Aradottir et al., 2001); marked efficacy against chronic meningoencephalitis (78\% improvement adverse effects been minimal) (Rotbart and Webster, 2001); no efficacy in another double-blind trial in children with enteroviral meningitis, twice as many adverse effects have been registered (Abzug et al., 2003); in phase III double-blind placebo-controlled trial some efficacy was shown in coxsackievirus rhinovirus A21-induced respiratory infections (common cold) when the treatment start within 24 hours of symptom onset (Hayden et al., 2003); drug-increased levels of the CYP3A4 liver microsomal enzyme stopped further trials, as decided by FDA in 2002 (Senior, 2002).

Schering-Plough carried in 2006-07 a placebo-controlled study of the effects of pleconaril nasal spray on common cold symptoms and asthma exacerbations following rhinovirus exposure (Clinical Trials.gov.U.S.NIH, 2007), the results of which have not yet been announced. In meanwhile, pleconaril manifested properties of a virucidal for hand treatments for prevention of rhinovirus infection (Turner and Hendley, 2005).

- BTA-798 (oxime ether analogue of pirodavir) - company Biota Scientific Management Pty Ltd scheduled a phase II of placebo-controlled double-blind clinical trial of this compound in asthmatic adults with symptomatic rhinovirus infection, starting on August 2010. This study is ongoing, but there are no information about the course and results till February 8th, 2012 (according FDA) (Clinical Trials.gov Identifier: NCT01175226).

\section{The drug-resistance problem}

At present it is explicitly demonstrated that the main reason for the lack of antivirals in clinical use for enterovirus infections is the development of drug-resistance. The first description of drug-resistance in enteroviruses is done by Melnick et al. as early as in 1961. Later drug-resistant enterovirus mutants have been isolated to approximately all specific enteroviral replication inhibitors (Loddo, 1980). Since this time Herrmann and Herrmann (1977) have postulated that the drug-resistance development is an indicator of the specific antiviral activity.

The resistance to one of the best inhibitors of enteroviruses, the WIN compound disoxaril, was studied by our research team either in vitro, or in vivo (in mice) in an experimental coxsackie B (CV-B) virus infection. The tracing of a panel of phenotypic markers for the characterization of disoxaril drug-resistant and drug-dependent mutants is introduced as a very important stage in the study of enterovirus inhibitors (Table 3) (Nikolova and Galabov, 2003). Moreover, our findings represent the first development of drug-resistance to a WIN compound on a model in vivo. Our experiments reveal that the failure of the disoxaril treatment course is due to the accumulation of drug-resistant progeny in the target organ, i.e. the mouse brain. The in vivo and in vitro generated disoxaril-resistant CV-B1 mutants demonstrate almost identical phenotype characteristics. The determination of specific phenotypic markers in the drug resistant progeny is of a special 
importance and is recommended as an obligatory requirement in the experimental chemotherapy of viral infections in general.

The molecular genetic analysis of the primary structure of CV-B1 VP1 mutants of the internal segment 196-258 showed that it is highly changed in the disoxaril-resistant and in disoxaril-dependent mutants in comparison to referent wild disoxaril-sensitive (REF/SOF) structures (Nikolova et al., 2011). The sequence changes obtained give a satisfactory ex- planation for the mutant resistance. However, the CV-B1 disoxaril-dependent mutation and mutant behavior cannot be explained based on 1D-sequencing only. The experimental evidence that CV-B1/disoxaril-dependent mutant needs disoxaril to provoke virus coating requires further studies to determine the 3D structure of the target VP1 protein. Such approach could contribute to the characterization of the CVB1/disoxaril-resistant mutant and would clarify the nature of disoxaril-resistance and dependence.

Table 3

Phenotypic characteristics of disoxaril mutants of CVB1 strains

\begin{tabular}{cccccc}
\hline $\begin{array}{c}\text { CVB1 } \\
\text { disoxaril } \\
\text { mutants }\end{array}$ & $\begin{array}{c}\mathrm{MIC}_{50} \\
{[\mu \mathrm{mol} / \mathrm{L}]}\end{array}$ & $\begin{array}{c}\text { Plaque } \\
\text { diameter } \\
{[\mathrm{mm}]}\end{array}$ & $\begin{array}{c}\text { Plaque } \\
\text { shape }\end{array}$ & $\begin{array}{c}\text { Stability at } \\
50^{\circ} \mathrm{CET}_{50}{ }^{\mathrm{a}} \\
{[\mathrm{min}]}\end{array}$ & $\begin{array}{c}\text { Pathogenicity } \\
\text { for mice }\end{array}$ \\
\hline $\mathrm{CVB} 1 / \mathrm{SOF}$ & 0.84 & $0.9 \pm 0.3$ & round & 31 & normal \\
\hline $\mathrm{CVB} 1 / \mathrm{RES}$ & $>30.0$ & $1.9 \pm 0.1^{*}$ & irregular & 7 & $\begin{array}{c}\text { slightly } \\
\text { increased }\end{array}$ \\
\hline $\mathrm{CVB} 1 / \mathrm{DEP}$ & --- & $1.9 \pm 0.1$ & irregular & 23 & normal \\
\hline
\end{tabular}

${ }^{\mathrm{a}} \mathrm{ET}_{50}$, effective time $50 \%$ : the time (in minutes) necessary for a $50 \%$ reduction of the infectious virus titer $* \mathrm{p}<0.001$ for CVB1/RES vs. CVB1/SOF mutants, Student's $t$-test.

\section{Combinations of antivirals against enteroviruses}

Till recently mono-therapy courses have been the only approach for experimental antienterovirus chemotherapy. The resistance occurring after mono-therapy with a certain drug makes it reasonable to focus the interest on the combined administration of antiviral compounds. This approach has proven its efficacy against HIV and HCV infections and is considered as a perspective tool to be applied in a situation of pandemic flu as well. Using combined synergistic therapy, a greater effect could be achieved at lower concentrations than those required if drugs were used alone and thus the so-called "pressure of the dose" effect which favors the rapid selection of resistant mutants, would be prevented. And what is especially important and highly awaited: combining drugs would restrain the resistance phenomenon.

Testing the combined effect of selective enterovirus replication inhibitors with different mode of action is also introduced by our research team. A large-scale study of combina- tions has been carried out. The research on the character of the combined effects begins by careful selection of the partners. This enables the precise application of the 3D model for characterization of drug interactions, developed by Prichard and Shipman in 1990. Thus, the synergistic effect in vitro and in vivo, of the dual combination between enviroxime and disoxaril against the replication of coxsackievirus B1 has been established (Nikolaeva and Galabov, 2000, 2004). The interactions between a series of picornavirus replication inhibitors (enviroxime, disoxaril, arildone, S-7, guanidine, PTU-23, HBB and oxoglaucine) in dual combinations has been also estimated (Nikolaeva and Galabov, 1995, 1999a,b, 2000, 2004). This large-scale study resulted in the selection of several effective double combinations with synergistic character of the combined effect in vitro.

Due to the multiple virus replication cycles taking place in the presence of the partner substances in the combinations, even the application of synergistic ones with a proven activity in vitro does not guarantee that occur- 
rence of single or multiple drug resistance shall be avoided.

An entirely different approach to combined application of antivirals is proposed here the consecutive alternating administration (CAA) of triple combinations of enterovirus replication inhibitors with different mode of action. In a recent study of ours we have examined this novel approach consisting of a consecutive and alternating, not simultaneous, application of the compounds in a combination on the model of an enterovirus infection in newborn mice. The first in vivo experimental model used has been the neurotropic CV-B1 infection (VassilevaPencheva and Galabov, 2010). Four compounds differing in their mode of antiviral action are selected for consecutive and alternating application: disoxaril (the pocket blocker, extensively studied in our laboratory, that has been established as a favorable partner in a series of synergistic combinations in vitro and in vivo), guanidine hydrochloride (targeting $2 \mathrm{C}$ viral protein), PTU-23 (viral RNA synthesis inhibitor, an original compound developed in our laboratory) and oxoglaucine (another original compound developed in the laboratory which attacks an early step in the virus growth cycle). The triple combination for consecutive application of disoxaril, guanidine. $\mathrm{HCl}$ and oxoglaucine (DGO), applied in the order of mentioning, shows a marked in vivo efficacy, expressed in a reduction of the mortality rate and lengthening of the mean survival time with 4 days as compared to that in both the placebo group, the groups in which each compound is applied daily alone, or the group when the triple combination is simultaneously applied every day (Fig. 1). The treatment course with the DGO combination applied simultaneously results in a well expressed development of resistance to the partners. In contrast, the consecutive and alternating application of DGO results in a strong reduction of the virus content in the brain $(99.9 \%$ - on the day $4,96.8 \%$ - on day $5,94.8 \%$ - on day 6 and $98.7 \%$ - on day 7). The drug sensitivity to the partners is not only preserved but even increased through the treatment course (Table 4). Thus, it is demonstrated for the first time that preservation of the antiviral activity is possible if a triple combination of anti-enteroviral inhibitors is applied in a consecutive and alternating manner (not simultaneously) (Vassileva-Pencheva and Galabov, 2010).

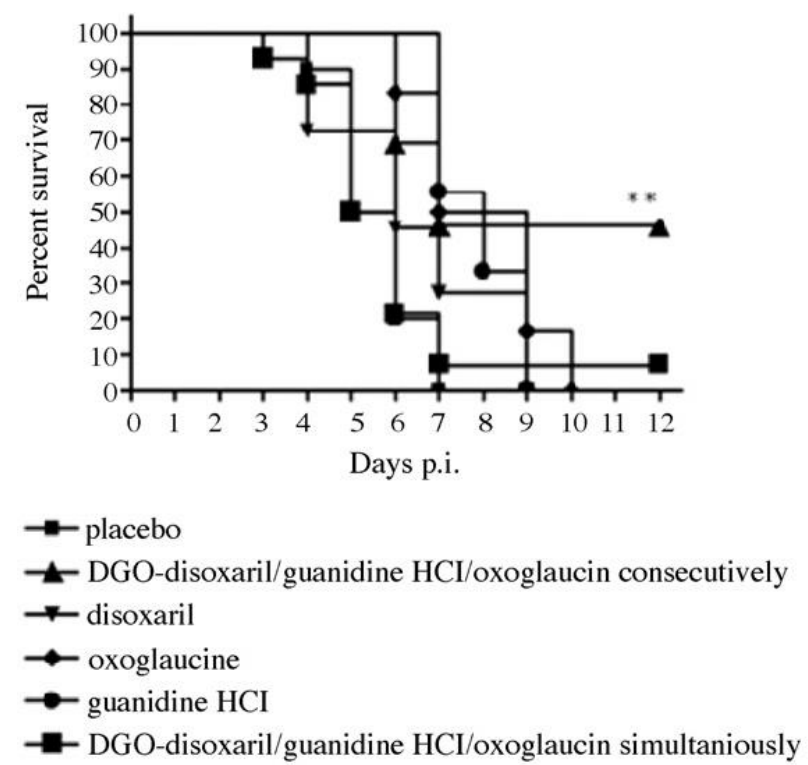

- DGO-disoxaril/guanidine HCI/oxoglaucin simultaniously

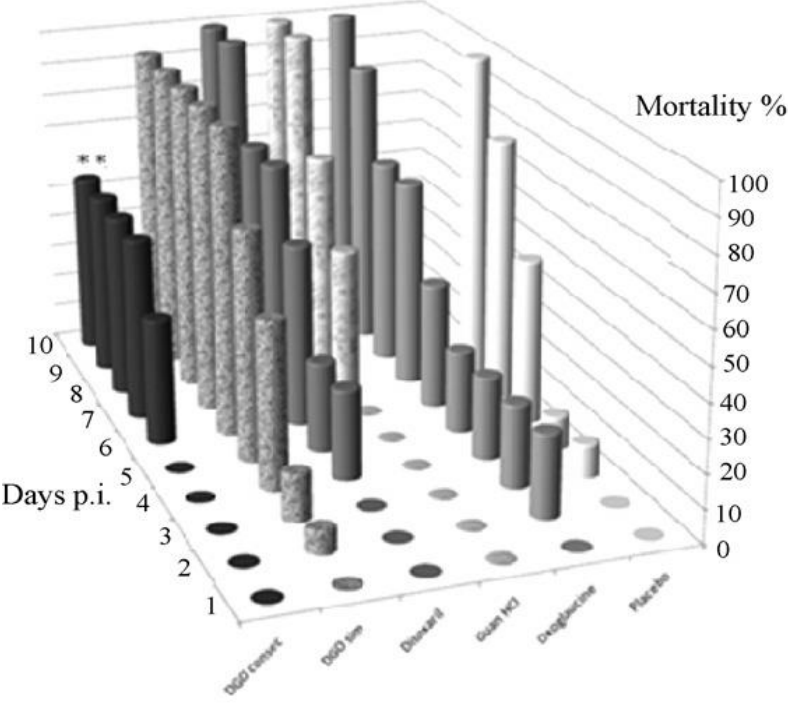

$* * \mathrm{P}<0.005$ compared to placebo. Statistical analysis was determined 7 by log rank test.

Figure 1 - Survival proportions of triple combination DGO vs. the effect of individual mono-therapies of the partners and the effect of the same combination DGO in which the inhibitors are given simultaneously 
Table 4

Sensitivity to disoxaril in the plaque-inhibition test of virus brain isolates from DGO treated and treated with disoxaril alone newborn mice, infected with CVB1

\begin{tabular}{|c|c|c|c|c|c|c|c|}
\hline \multirow[t]{2}{*}{$\begin{array}{l}\text { Test group/ } \\
\text { Brain sample }\end{array}$} & \multicolumn{7}{|c|}{$\begin{array}{l}\text { Disoxaril IC } 50 \text { values ( } \mu \mathrm{M}) \text { of viral brain samples } \\
\text { taken on day (after viral inoculation) }\end{array}$} \\
\hline & 4 & 5 & 6 & 7 & 8 & 9 & 10 \\
\hline \multicolumn{8}{|l|}{ Plaque purified } \\
\hline Placebo & 0.38 & 0.4 & 0.5 & 0.57 & $-\mathrm{b}$ & $-\mathrm{b}$ & $-\mathrm{b}$ \\
\hline Disoxaril & $-^{\mathrm{a}}$ & 1.71 & 3.03 & $11.1^{*}$ & $-\mathrm{b}$ & $-b$ & $-\mathrm{b}$ \\
\hline DGO & 0.55 & 0.52 & 0.64 & $0.09^{\natural}$ & 0.12 & 0.08 & 0.13 \\
\hline \multicolumn{8}{|l|}{$\underline{\text { Native }}$} \\
\hline Placebo & 0.45 & 0.42 & 0.55 & 0.59 & $\mathrm{-a}^{\mathrm{a}}$ & $\mathrm{-a}^{\mathrm{a}}$ & $-^{\mathrm{a}}$ \\
\hline Disoxaril & $-\mathrm{b}$ & 2.53 & 5.95 & 14.7 & $-^{\mathrm{a}}$ & $\mathrm{a}^{\mathrm{a}}$ & $-^{\mathrm{a}}$ \\
\hline DGO consecu-Tively & 0.54 & 1.5 & 0.19 & 0.08 & 0.1 & 0.09 & 0.14 \\
\hline DGO simulta-neously & 1.7 & 1.64 & 5.82 & 16.3 & $-{ }^{\mathrm{a}}$ & $\mathrm{a}^{\mathrm{a}}$ & $-^{\mathrm{a}}$ \\
\hline
\end{tabular}

${ }^{*} \mathrm{P}<0.05$ compared to the placebo group. ${ }^{\natural} \mathrm{P}<0.05$ compared to the group treated with disoxaril alone. The statistical analysis was performed with one-way ANOVA with Bonferroni's Post test. ${ }^{\text {a }}$ - due to $100 \%$ inhibitory effect of disoxaril on day 4 there is no infectious virus in the brain isolate. ${ }^{\mathrm{b}}$ - after day 7 there are no left alive animals, $100 \%$ mortality rate.

Our model of a triple combination and the entirely different approach for a conescutive application of the partners undoubtedly prevents the occurrence of resistance, which is in a full contrast to the multiple drug-resistance established in the regimens when compounds are administered simultaneously every day. The way of ordering the partners plays a key role for the effectiveness of the combination. The proposed novel regimen for a combined chemotherapy must start with an inhibitor of an early step of the viral cycle, e.g. disoxaril, and must be followed by a RNA replication inhibitor, such as guanidine. $\mathrm{HCl}$, and then one that targets an early step again, like oxoglaucine. This treatment course confirmed its efficacy in three models of CVB infections in vivo. (Vassileva-Pencheva and Galabov, 2010; VassilevaPencheva and Galabov, unpublished data). The CAA treatment course confirmed its efficacy in CV-B1 neuroinfection in mice through replacing disoxaril with another WIN compound pleconaril (Stoyanova et al., unpublished data).

We assume that other successful models of consecutively administered triple combinations could be researched and developed and that would be the basis of a new therapeutic strategy.

\section{REFERENCES}

Abzug MJ, Cloud G, Bradley J, Sanchez PJ, Romero J, Powell D, et al. Double blind placebo-controlled trial of pleconaril in inmfants with enterovirus meningitis. Pediatr Infect Dis. 2003; 36: 1523-1532.

Aitken C, Jeffries DJ Nosocomial spread of viral disease. Clinical Microbiology Review. 2001; 14: 528-546.

Archard LC, Richardson PJ, Olsen EG, Dubowitz V, Sewry C, Bowles NE. The role of coxsackie B viruses in the pathogenesis of myocarditis, dilated cardiomyopathy and inflammatory muscle disease. Biochem Soc Symp. 1987; 53: 51-62.

Aradottir E., Alonso EM, Shulman ST. Severe neonatal enteroviral hepatitis treated with plrconaril. Pediatr Infect Dis. 2001; 20: 457-459.

Chuang JH. (Enterovirus surveillance may be insufficient for estimating burden in Taiwan. Presented at: $14^{\text {th }}$ International Congress on Infectious Diseases, March 9-12 ${ }^{\text {th }}, 2010$; Miami, USA. Poster \#40.005. 2010.

Diana GD, Rudewicz P., Pevear DC, Nitz TJ, Aldous SC, Robinson DT, et al. Picornavirus inhibitors: Trifluromethyl substitution provides a global protective effect against hepatic metabolism. J Med Chem. 1995; 38: 1355-1371.

Galabov AS, Angelova A. Antiviral agents in the prevention and treatment of virus-induced diabetes. 
Anti-Infective Agents in Medicinal Chemistry. 2006; 5: 293-307.

Hayden FG, Herrington DT, Coats TL, Kim K, Cooper EC, Villano SA, et al. Efficacy and safety of oral pleconaril for treatment of colds due to picornaviruses in adults: Results of 2 double-blind, randomized, placebo-controlled trials. Clin Inf Dis. 2003; 36: 1523-1532.

Herrmann EC Jr, Herrmann JA. A working hypothesis virus resistance development as an indicator of specific antiviral activity. Ann NY Acad Sci. 1977; 284: 632-637.

Herrmann EC Jr, Herrmann JA, DeLong DC. Prevention of death in mice infected with coxsackievirus A16 using guanidine $\mathrm{HCl}$ mixed with substituted benzimidazoles. Antiviral Res. 1982; 2: 339-346.

Hyoty H, Taylor KW. The role of viruses in human diabetes. Diabetologia. 2002; 45: 1353-1361

Loddo B. Development of drug resistance and dependence in viruses. Pharm Ther. 1980; 10: 431-460

Mallia P, Contoli M, Caramori G, Pandit A, Johnston SL, Papi A. Exacerbations of asthma and chronic obstructive pulmonary disease (COPD): focus on virus induced exacerbations. Current pahrmaceutical Design. 2007; 13: 73-97.

Melnick JL, Crowther D, Barrera-Oro J. Rapid development of drug-resistant mutants of poliovirus. Science. 1961; 134: 557-557.

Morens DM, Pallansch MA. Epidemiology. In: Rotbart HA (ed) Human Enterovirus Infections. Washington DC ASM Press. 1995.

Nikolaeva L, Galabov AS. Synergistic inhibitory effect of enviroxime and disoxaril on poliovirus type 1 replication. Acta virol. 1995; 39: 235-241.

Nikolaeva L, Galabov AS. Cytotoxicity of the synergistic antienteroviral combination of enviroxime and disoxaril. Acta virol. 1999a; 43: 263-265.

Nikolaeva L, Galabov AS. In vitro inhibitory effects of dual combinations of picornavirus replication inhibittors. Acta virol. 1999b; 43: 303-311.

Nikolaeva L, Galabov AS. Antiviral effect of the combination of enviroxim and disoxaril on Coxsackievirus B1 infection. Acta virol. 2000; 44: 73-78.

Nikolaeva-Glomb L, Galabov AS. Synergistic drug combinations against the in vitro replication of Coxackie B1 virus. Antiviral Res. 2004; 16: 41-46.

Nikolova I, Galabov AS. Development of resistance to disoxaril in coxsackie B1 virus infected newborn mice. Antivir Res. 2003; 60: 35-40.

Pallansch M, Roos R. Enteroviruses: Polioviruses, coxsackieviruses, echoviruses and newer enteroviruses. In: Knipe DM, Howley PM (ed) Fields Virology, Fifth Edition, Philadelphia, Lippincott Williams \& Wilkins. 2006; pp. 895-910.

Pallansch MA. Enterovirus infections, including poliomyelitis. In: Guerrant RL, Walker DH, Weller PF (ed) Tropical Infectious Diseases. Principles, Pathogens and Practice. 3rd edn. 2011.

Prichard MN, Shipman CJr. A three-dimensional model to analyze drug-drug interactions. Antiviral Res. 1990; 14: 181-206.
Rotbart HA, Webster AD. Treatment of potentially lifethreatening enterovirus infections with plrconaril. Clin Infect Dis. 2001; 32: 228-235.

Schultheiss HP, Kuhl U. Overview on chronic viral cardiomyopathy/chronic myocarditis. Ernst Schering Res Found Workshop. 2006; 55: 3-18.

Senior K. FDA panel rejects common cold treatment. Lancet Infect Dis. 2002; 2: 264.

Strauss J, Strauss E. Plus-Strand RNA Viruses. In: Viruses and Human Disease. 2008; pp 63-136.

Tan W C. Viruses in asthma exacerbations. Current Opinion in Pulmonary Medicine. 2005; 11: 21-26.

Tauriainen S, Oikarinen S, Oikarinen M, Hyöty H. Enteroviruses in the pathogenesis of type 1 diabetes. Semin Immunopathol. 2011; 33: 45-55.

Turner RB, Dutko FJ, Goldstein NH, Lockwood G, Hayden FG. Efficacy of oral WIN 54954 for prophylaxis of experimental rhinovirus infection. Antimicrob Agents Chemother. 1993; 33: 2069-2074.

Turner RB, Hendley O. Virucidal hand treatments for prevention of rhinovirus infection. J Antimicrob Chemother. 2005; 56: 805-807.

Vassileva-Pencheva R, Galabov AS. Avoiding drug-resistance development by novel approach of combining enteroviral substances against coxsackievirus B1 infection in mice. Antiviral Res. 2010; 85: 366-372.

Резиме

\section{АНТИВИРУСЕН КОМБИНИРАН ПРИСТАП КАКО ПЕРСПЕКТИВА ВО БОРБАТА СО ЕНТЕРОВИРУСНИТЕ ИНФЕКЦИИ}

\section{Ангел С. Галабов, Иванка Николова, Ралица Василева-Пенчева, Аделина Стојанова}

Институт за микробиологија, „Стефан Ангелов“, Бугарска академија на науките, Софија, Бугарија

Хуманите ентеровируси дистрибуирани низ целиот свет се предизвикувачки агенси на широк спектар на болести со екстремно висок морбидитет, вклучително и серија тешки болести на централниот нервен систем, срцето, ендокриниот панкреас, мускулите на скелетот, итн., како и обичната настинка што придонесува за развој на хроничните респираторни болести, вклучувајќи го хроничното опструктивно белодробно заболување. Горенаведените болести, заедно со значително високиот морбидитет и морталитет кај децата, како и кај популациите со висок ризик (имунодефициенција, новородени), дефинитивно, ја формулираат хемотерапијата како главна алатка за контрола на ентерови- 
русните инфекции. Во моментов не постојат клинички ефективни антивирусни лекови за употреба во лекувањето на ентеровирусната инфекција, и покрај големиот труд вложен на ова поле. Главна причина за ова е развојот на отпорноста на лекови. Ние го студиравме процесот на развој на отпорноста на најсилните инхибитори на ентеровируси, WIN-соединенија (VP1 protein hydrophobic pocket blockers), особено кај моделите ин виво, Coxsackievius B (CV-B) инфекциите кај глувците. Воведовме следење на панел на фенотипските маркери $\left(\mathrm{MIC}_{50}\right.$ вредност, обликот и големина на плочката, стабилност на $50^{\circ} \mathrm{C}$, патогеноста кај глувци) за карактеризација на лековите-мутанти (отпорни и зависни), како многу важна фаза во студијата на ентеровирусните инхибитори. Згора на тоа, како резултат на VP1 PHK секвентната анализа направена врз модел на disoxaril мутанти на CVB1, ја одредивме молекуларната основа на отпорноста на лекови.

Монотерапевтските начини беа единствениот пристап што се користеше досега. Прв пат во истражувањето на антиентеровирусните антивируси нашиот тим воведе тестирање на комбиниран ефект на селективни инхибитори на ентеровирусна репликација со различен начин на дејство. Ова истражување резултираше со избор на голем број многу ефикасни ин витро двојни комбинации со синергистичко дејство и широк спектар на чувствителни ентеровируси. Најпроспективното постигнување во нашите истражувања од оваа област беше развојот на нова шема за комбинираната примена на антиентеровирусните супстанции во coxsackievirus B1 невроинфекцијата кај новородени глувци. Тоа се состоеше од последователно, наизменично и несимултано давање на супстанциите во комбинација. Тројната комбинација - disoxaril-guanidine. HCl-oxoglaucine (DGO) покажа висока ефикасност изразена во означено намалување на стапката на смртност кај заразените глувци во споредба со плацебо-групата, и со партнерските соединенија што се користат сами секој ден, а на истата комбинација што се применува истовремено секој ден. Студиите за чувствителноста на изолатите на вирус од мозок од глувци, третирани со DGO-комбинација, покажаа не само зачувана, но дури и зголемена чувствителност на лековите вклучени во комбинацијата. Очигледно, последователното наизменично давање антиентеровирусни супстанции го спречува јавувањето на отпорност на лекови во текот на експерименталната ентеровирусна инфекција кај глувците.

Клучни зборови: ентеровируси, антивирусни, отпорност на лекови, комбинирани ефекти. 